\title{
Cortisol modulates vasotocinergic and isotocinergic pathways in the gilthead sea bream
}

\author{
Laura Cádiz ${ }^{1,2, \ddagger}$, Javier Román-Padilla ${ }^{1, *}$, Magdalena Gozdowska ${ }^{3}$, Ewa Kulczykowska ${ }^{3}$, \\ Gonzalo Martínez-Rodríguez ${ }^{2}$, Juan M. Mancera ${ }^{1}$ and Juan A. Martos-Sitcha ${ }^{1,2, \pm, \S}$
}

\begin{abstract}
In the present study, we assessed the responses of the vasotocinergic and isotocinergic systems to chronic stress induced by cortisol administration in the gilthead sea bream (Sparus aurata). Pituitary and plasma arginine vasotocin (AVT) and isotocin (IT) levels, as well as hypothalamic pro-vasotocin (pro-VT) and pro-isotocin (proIT) mRNA expression levels, were analysed. In addition, the mRNA levels of three receptors, AVTR type V1a2, AVTR type V2 and ITR, were analysed in several target organs associated with the following physiological processes: (i) integration and control (hypothalamus), (ii) metabolism and its control (liver and hypothalamus), (iii) osmoregulation (gills) and (iv) stress response (head kidney). Specimens were injected intraperitoneally with slow-release implants ( $5 \mu \mathrm{L} \mathrm{g}^{-1}$ body mass) containing coconut oil alone (control group) or with cortisol (50 $\mathrm{\mu g} \mathrm{g}^{-1}$ body mass; cortisol group). Both AVT and IT synthesis and release were correlated with plasma cortisol values, suggesting a potential interaction between both hormonal systems and cortisol administration. Our results suggest that the activation of hepatic metabolism as well as the hypothalamic control of metabolic processes provide the energy necessary to overcome stress, which could be partly mediated by AVTRs and ITR. Upregulation of branchial AVT and IT receptor expression following cortisol treatment suggests an involvement of the vasotocinergic and isotocinergic systems in the regulation of ion channels/transporters during stressful situations. Finally, changes in AVT and IT receptor mRNA expression in the head kidney suggest these nonapeptides participate in feedback mechanisms that regulate the synthesis/release of cortisol. Our results indicate a relationship between cortisol and both the vasotocinergic and isotocinergic systems during simulated chronic stress in S. aurata.
\end{abstract}

KEY WORDS: Cortisol, Isotocin, Receptors, Sparus aurata, Stress, Vasotocin

\section{INTRODUCTION}

In teleosts, the neurohypophyseal hormones arginine vasotocin (AVT) and isotocin (IT), which are structurally and functionally similar to arginine vasopressin (AVP) and oxytocin (OXY) in

${ }^{1}$ Department of Biology, Faculty of Marine and Environmental Sciences, University of Cádiz, 11510 Puerto Real, Cádiz, Spain. ${ }^{2}$ Instituto de Ciencias Marinas de Andalucía, Consejo Superior de Investigaciones Científicas (ICMAN-CSIC), 11510 Puerto Real, Cádiz, Spain. ${ }^{3}$ Department of Genetics and Marine Biotechnology, Institute of Oceanology of the Polish Academy of Sciences, 81-712 Sopot Poland

*Present address: IFAPA Centro ‘El Toruño', Junta de Andalucía, 11500 El Puerto de Santa María, Cádiz, Spain

抽ese authors contributed equally to this work

§Author for correspondence (juanantonio.sitcha@uca.es)

Received 14 September 2014; Accepted 27 November 2014 mammals, are synthesised in the magnocellular and parvocellular hypothalamic nuclei and released in the neurohypophysis, and participate in numerous physiological processes. AVT is involved in osmoregulatory processes (primarily adaptation to hyperosmotic environments because of its antidiuretic role), control of blood pressure and cardiovascular activity, metabolism and stress, reproductive behaviour, brain neurotransmission and pituitary endocrine activity (Warne et al., 2002; Balment et al., 2006; Kulczykowska, 2007). Although many basic questions remain concerning the role of IT, recent studies in fish have demonstrated that IT levels in the brain vary according to reproductive stage, social status and behaviour (Almeida et al., 2012; Kleszczyńska et al., 2012). Both the vasotocinergic and isotocinergic systems are complex and controlled by many external and internal factors. Furthermore, plasma AVT and IT expression is controlled on multiple levels, including transcription and peptide synthesis, maturation, transport, storage and release. Both hormones initiate their physiological activities by interacting with specific receptors within target tissues (Goossens et al., 1977; van den Dungen et al., 1982; Acher, 1993; Acher and Chauvet, 1995; Goodson and Bass, 2000). Therefore, the presence of AVT and/or IT receptors (AVTR and ITR, respectively; members of the G-protein coupled receptor family) in specific tissues or organs suggests that these systems are involved in their physiological function (Mahlmann et al., 1994; Hausmann et al., 1995).

In teleosts, cortisol is the main steroid synthesised and released by interrenal cells located in the head kidney. This hormone is involved in many processes, including intermediary metabolism, osmotic and ionic regulation, growth, stress and immunity (Henderson and Garland, 1980; McCormick, 1995; Mommsen et al., 1999; Mancera and McCormick, 2007; Sherwani and Parwez, 2008). Hypothalamic neurons responsible for AVT and IT synthesis and secretion innervate adenohypophyseal corticotropin cells, which release adrenocorticotropic hormone (ACTH) into the bloodstream and control cortisol secretion from the head kidney (Fryer and Leung, 1982; Fryer et al., 1985; Baker et al., 1996). In addition, the colocalisation of AVT and corticotropin releasing factor (CRF) has been reported in hypothalamic neurons innervating corticotropin cells (Batten et al., 1990). These findings suggest that AVT (and/or IT) and cortisol may be co-regulated during certain processes (Moons et al., 1989; Baker et al., 1996; Kulczykowska, 2001; Sangiao-Alvarellos et al., 2006).

With respect to metabolism, more energy is required for homeostasis in animals subjected to stressful situations, with the liver serving as the most important organ for general fuel supplies (Sangiao-Alvarellos et al., 2003b; Sangiao-Alvarellos et al., 2005; Soengas et al., 2007). Furthermore, the brain (and in particular, the hypothalamus, a site of nonapeptide synthesis) is central to the control of hormone and paracrine factor production, as well as local responses to energy demands and metabolic pathways (Acher, 1993; 
Hylland et al., 1997; Purdon and Rapoport, 1998; Soengas and Aldegunde, 2002; Sangiao-Alvarellos et al., 2003a). The presence of AVTR/ITR in organs/tissues linked to metabolic control, together with functional changes following AVT/IT treatment, has been described in several fish species. Indeed, several studies have demonstrated that certain hormones and/or neurotransmitters stimulate energy metabolism in the brain and liver by increasing glycogenolytic pathways in various teleost species [Cyprinus carpio (Janssens and Lowrey, 1987), Anguilla rostrata (Moon and Mommsen, 1990), Sparus aurata (Sangiao-Alvarellos et al., 2004; Sangiao-Alvarellos et al., 2006)]. However, the functions of AVTR and ITR in the gills and head kidney have not been adequately addressed.

The gilthead sea bream ( $S$. aurata Linnaeus 1758) is a marine teleost of high commercial value, and it is widely cultured in the South Atlantic region of Spain, primarily in salt marshes, i.e. areas with strong weather-based fluctuations in salinity and temperature (Arias, 1976). Physiological plasticity in this euryhaline species is controlled by several pituitary hormones, including AVT and IT, as well as extrapituitary hormones, making $S$. aurata a good model for studies of the stress response (Mancera et al., 2002; Kleszczyńska et al., 2006; Mancera and Fuentes, 2006). Our research group has analysed various aspects of the vasotocinergic and isotocinergic systems of $S$. aurata in the context of osmoregulation, metabolism and multiple stressors (Kleszczyńska et al., 2006; Laiz-Carrión et al., 2002; Laiz-Carrión et al., 2005; Sangiao-Alvarellos et al., 2003b; Sangiao-Alvarellos et al., 2005; Sangiao-Alvarellos et al., 2006; Martos-Sitcha et al., 2013b). Recently, we cloned two distinct AVT receptors (AVTR V1a2 and V2) and one IT receptor (ITR), and we have characterised changes in the levels of these receptors during osmotic shifts (MartosSitcha et al., 2014a) and assessed their roles during intestinal ion transport (Martos-Sitcha et al., 2013a).

In this study, we comprehensively analysed the effects of cortisol treatment on the hypothalamic synthesis and pituitary release of AVT and IT, as well as on the expression levels of AVTR and ITR mRNA in various tissues (hypothalamus, liver, gill and head kidney) of the gilthead sea bream (S. aurata).

\section{RESULTS}

\section{Changes in plasma parameters}

In cortisol-treated specimens, plasma levels of this hormone were increased by $12 \mathrm{~h}$ post-injection. Cortisol levels gradually decreased, eventually reaching values similar to those in the control group by 10 days post-injection (Fig. 1). No significant changes were observed in control animals treated with coconut oil alone. The time course of plasma osmolality and metabolite changes in $S$. aurata specimens following cortisol injection is shown in Table 1. Cortisoltreated specimens showed a decrease in osmolality at $12 \mathrm{~h}$ postinjection, although osmolality had recovered to control levels by day 1. In both the control and cortisol-injected groups, plasma glucose levels first increased and then decreased along with plasma cortisol levels. After an initial but not significant decrease in plasma lactate levels, a posterior increase was observed on days 3 and 10 postinjection in the cortisol group. By contrast, the control group showed stable plasma osmolality and lactate values.

\section{AVT and IT synthesis and release}

The response time courses for hypothalamic pro-vasotocin (pro-VT) and pro-isotocin (pro-IT) mRNA expression, AVT/IT pituitary levels and circulating levels following cortisol treatment are shown in Figs 2-4, respectively. The control group did not show any changes

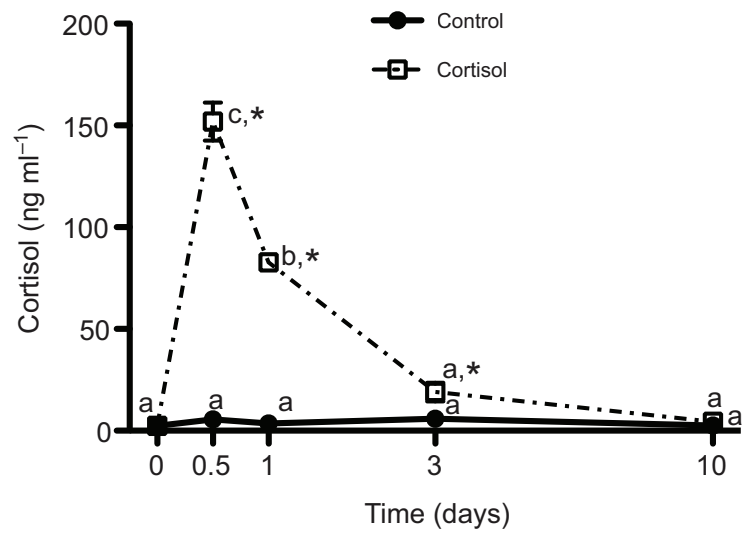

Fig. 1. Time course of changes in plasma cortisol levels in Sparus aurata specimens implanted i.p. with $5 \mu \mathrm{g} \mathrm{g}^{-1}$ body mass of coconut oil alone (control) or with cortisol (50 $\mathrm{g} \mathrm{g} \mathrm{g}^{-1}$ body mass). Values represent means \pm s.e.m. ( $N=9$ fish per group). Significant differences between sampling points within the same treatment are identified with different letters; different symbols indicate differences between groups at the same time point $(P<0.05$, two-way ANOVA followed by Tukey's test).

in hypothalamic pro-VT expression or pituitary AVT levels, whereas plasma AVT levels were increased by $12 \mathrm{~h}$ post-injection (Fig. 2A, Fig. 3A and Fig. 4A, respectively). However, hypothalamic pro-VT expression increased $12 \mathrm{~h}$ and 1 day post-injection in the cortisoltreated group, eventually decreasing to control levels (Fig. 2A). Pituitary AVT levels showed a trend that was identical to that of proVT expression, although with a lag of $12 \mathrm{~h}$ (Fig. 3A). A significant decrease in plasma AVT levels was observed from day 3 until the end of the experiment (Fig. 4A).

In the control group, a temporary increase in pro-IT mRNA expression and plasma IT levels was noted at $12 \mathrm{~h}$ post-injection (Fig. 2B and Fig. 4B), whereas in the cortisol-treated group, pro-IT mRNA expression rose temporarily over the first $24 \mathrm{~h}$. In both groups, pituitary IT storage significantly increased over the course of the experiment (Fig. 3B). Plasma IT levels increased significantly during the first $24 \mathrm{~h}$ in the cortisol-treated group and then declined sharply.

\section{Expression of AVT and IT receptor genes Hypothalamus}

Intraperitoneal (i.p.) injection of coconut oil alone (control group) did not induce significant changes in AVTR V2-type and ITR gene expression, although AVTR V1a2-type mRNA levels significantly increased during the first $12 \mathrm{~h}$, eventually returning to baseline values. By contrast, cortisol treatment decreased AVTR V1a2-type expression and increased AVTR V2-type and ITR mRNA expression from the beginning of the experiment until day 3 (Fig. 5).

\section{Liver}

In the control group, no changes were observed in AVTR or ITR mRNA expression. However, in the cortisol-treated group, clear increases were observed for the mRNA expression levels of all receptors tested (Fig. 6). The increases were significant between days 1 and 3 for AVTR V1a2 and V2 (Fig. 6A,B) and between days 3 and 10 for ITR (Fig. 6C).

\section{Gill}

In the control group, AVTR V1a2-type expression did not show significant changes, whereas AVTR V2-type and ITR gene expression increased until day 3 of the experiment, eventually 
Table 1. Time course of the changes in plasma osmolality and metabolite (glucose and lactate) levels in S. aurata specimens injected i.p. with $5 \mu \mathrm{g} \mathrm{g}^{-1}$ body mass coconut oil, either alone (control) or with cortisol ( $50 \mu \mathrm{g} \mathrm{g}^{-1}$ body mass)

\begin{tabular}{|c|c|c|c|c|c|c|}
\hline Parameter & Group & Day 0 & $12 \mathrm{~h}$ & Day 1 & Day 3 & Day 10 \\
\hline \multirow[t]{2}{*}{ Osmolality (mOsm kg${ }^{-1}$ ) } & Control & $306 \pm 4^{a}$ & $305 \pm 4^{a}$ & $303 \pm 4^{a}$ & $302 \pm 3^{\mathrm{a}}$ & $308 \pm 4^{a}$ \\
\hline & Cortisol & & $292 \pm 2^{b, *}$ & $303 \pm 2^{a}$ & $306 \pm 3^{a}$ & $302 \pm 4^{a}$ \\
\hline Glucose $\left(\mathrm{mmoll}^{-1}\right)$ & Control & $0.75 \pm 0.05^{\mathrm{a}}$ & $1.05 \pm 0.10^{b}$ & $1.11 \pm 0.09^{b}$ & $1.03 \pm 0.11^{\mathrm{a}, \mathrm{b}}$ & $0.91 \pm 0.11^{\mathrm{a}}$ \\
\hline \multirow[t]{2}{*}{ Lactate $\left(\mathrm{mmol} \mathrm{I}{ }^{-1}\right)$} & Control & $0.83 \pm 0.12^{\mathrm{a}}$ & $0.83 \pm 0.11^{\mathrm{a}}$ & $0.78 \pm 0.11^{\mathrm{a}}$ & $0.88 \pm 0.12^{\mathrm{a}}$ & $0.89 \pm 0.11^{a}$ \\
\hline & Cortisol & & $0.62 \pm 0.10^{a}$ & $0.79 \pm 0.12^{\mathrm{a}}$ & $1.12 \pm 0.13^{b}$ & $1.16 \pm 0.12^{b}$ \\
\hline
\end{tabular}

Values represent means \pm s.e.m. ( $N=9$ fish per group). Significant differences between sampling points within the same treatment are identified with different superscript letters; different symbols indicate differences between groups at the same time point $(P<0.05$, two-way ANOVA followed by Tukey's test).

returning to the values observed in the untreated group (day 0). The cortisol-treated group showed significant increases in mRNA expression for the three tested receptors from $12 \mathrm{~h}$ until $1-3$ days post-injection, eventually returning to the values observed in the control group by the end of the experiment (Fig. 7).

\section{Head kidney}

In the control group, no changes were observed in the mRNA expression levels of either AVTR-type, whereas in the cortisolinjected group, significant increases in mRNA expression were observed for both receptors over the course of the experiment (Fig. 8A,B). In the control group, ITR mRNA expression was decreased at $12 \mathrm{~h}$ and 1 day post-injection, recovering to initial values by day 3 . In the cortisol-treated group, expression was
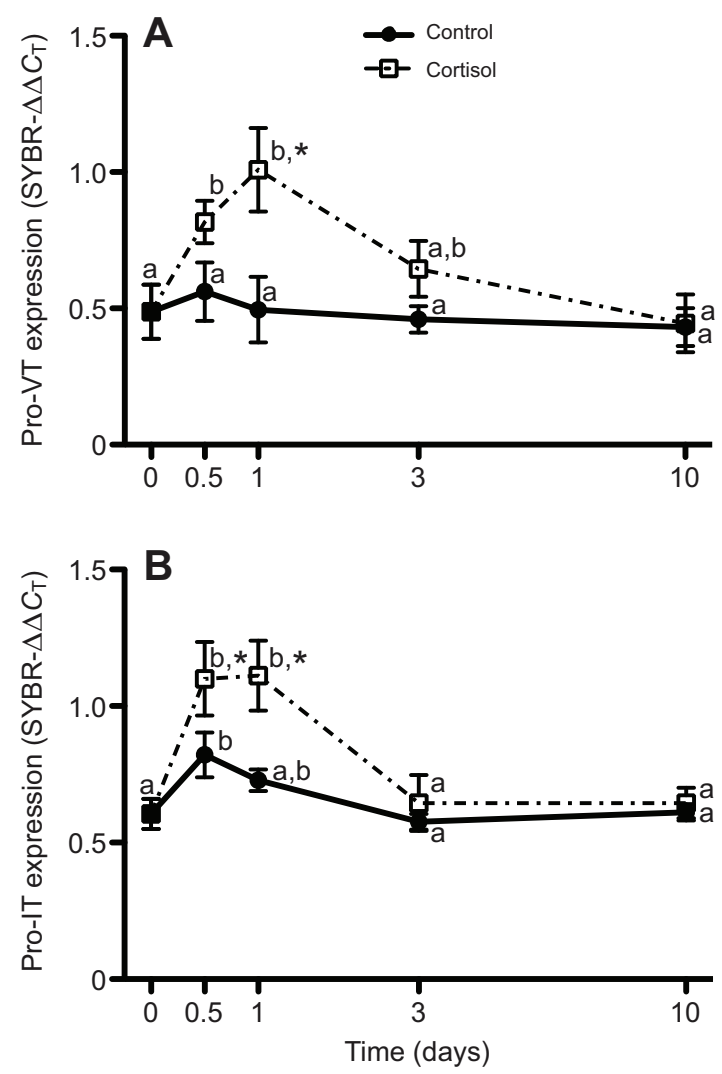

Fig. 2. Time course of changes in hypothalamic pro-vasotocin and proisotocin mRNA expression levels in $S$. aurata specimens implanted i.p. with $5 \mu \mathrm{g}^{-1}$ body mass of coconut oil alone (control) or with cortisol $\left(50 \mathrm{\mu g} \mathrm{g}^{-1}\right.$ body mass). Pro-vasotocin (pro-VT, A) and pro-isotocin (pro-IT, B) mRNA expression levels are given relative to $\beta$-actin expression. For further details, see the legend of Fig. 1. decreased from $12 \mathrm{~h}$ post-injection and remained low until the end of the experiment (Fig. 8C).

\section{DISCUSSION}

Several aspects of the vasotocinergic and isotocinergic systems have been previously characterised in the gilthead sea bream (S. aurata), and these systems have been putatively linked to several physiological processes, including osmoregulation (Kleszczyńska et al., 2006; Martos-Sitcha et al., 2013a; Martos-Sitcha et al., 2013b; Martos-Sitcha et al., 2014a), metabolism (Sangiao-Alvarellos et al., 2004; Sangiao-Alvarellos et al., 2006), and stress due to starvation and high stocking density (Mancera et al., 2008). However, relatively few studies have examined the link between stress pathway activation by cortisol and the vasotocinergic and isotocinergic systems. Recently, in vitro studies performed in the gilthead sea bream demonstrated for the first time that AVT and IT
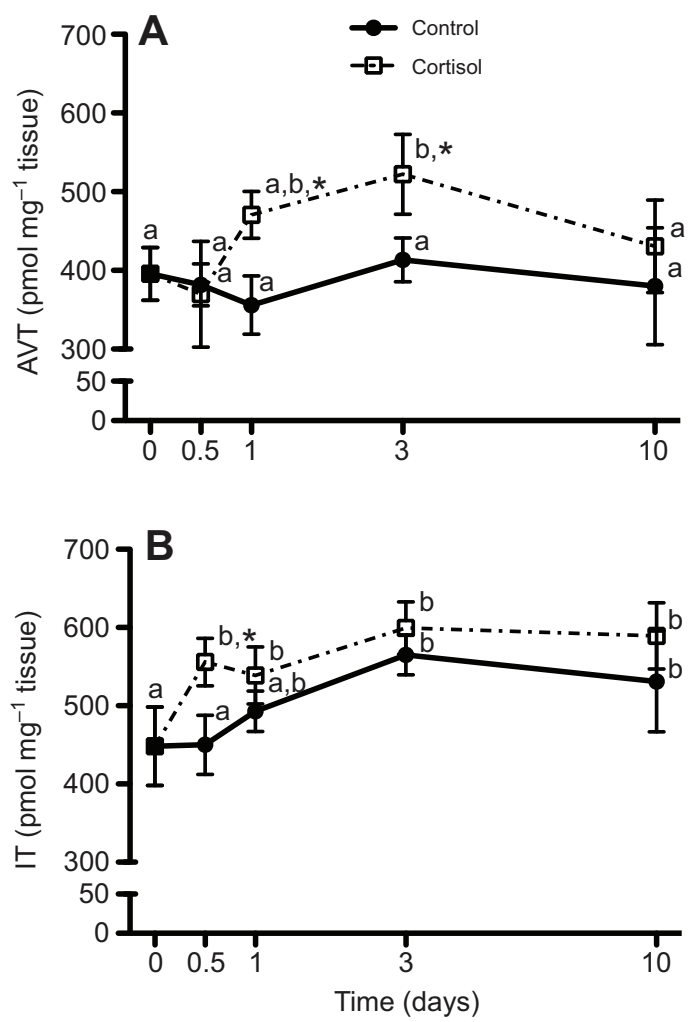

Fig. 3. Time course of changes in arginine vasotocin and isotocin pituitary storage levels in S. aurata specimens implanted i.p. with $5 \mu \mathrm{g}^{-1}$ body mass of coconut oil alone (control) or with cortisol ( $50 \mathrm{\mu g} \mathrm{g}^{-1}$ body mass). (A) Arginine vasotocin (AVT) and (B) isotocin (IT). For further details, see the legend of Fig. 1. 

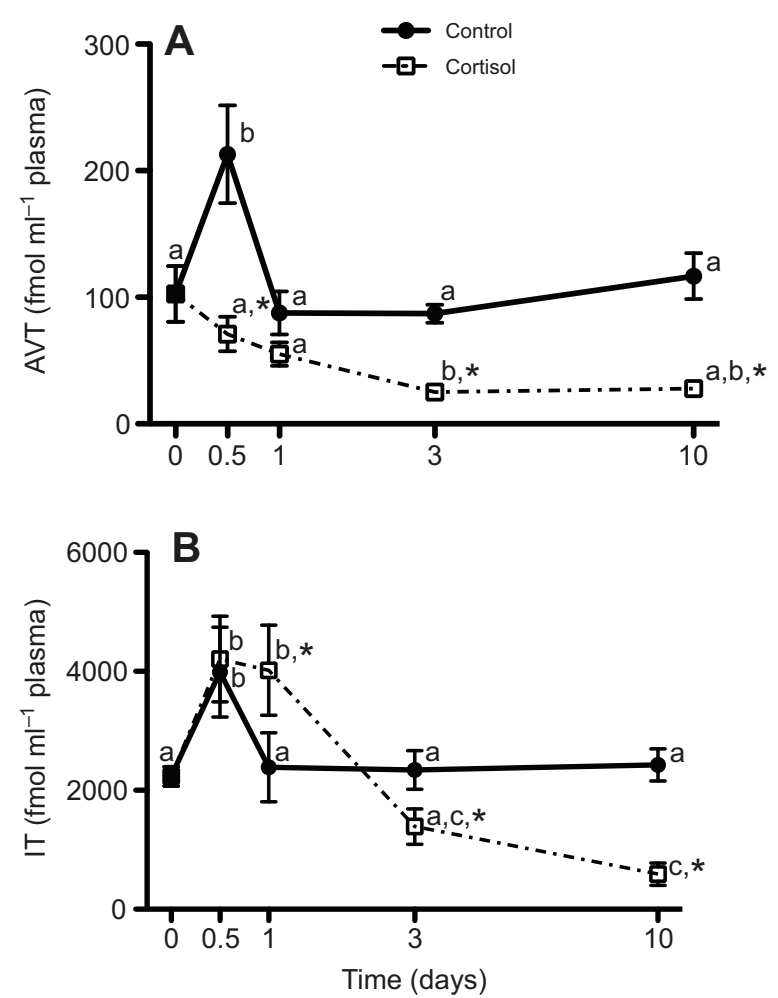

Fig. 4. Time course of changes in AVT and IT plasma levels in S. aurata specimens implanted i.p. with $5 \mu \mathrm{g} \mathrm{g}^{-1}$ body mass of coconut oil alone (control) or with cortisol ( $50 \mathrm{\mu g} \mathrm{g}^{-1}$ body mass). (A) AVT and (B) IT. For further details, see the legend of Fig. 1.

secretion from pituitary cells is influenced by cortisol, which induced AVT and inhibited IT secretion (Kalamarz-Kubiak et al., 2014).

\section{Changes in plasma levels}

Intraperitoneal injection of slow release implants containing coconut oil with cortisol have previously been used to induce sustained increases in plasma cortisol concentrations (Laiz-Carrión et al., 2002; Laiz-Carrión et al., 2003). We found that plasma cortisol levels did not show large variations in the control group, whereas levels had significantly increased in the cortisol-treated group by $12 \mathrm{~h}$ post-injection (Fig. 1). In a previous study involving S. aurata using identical cortisol doses and administration procedures, the higher plasma levels of this hormone induced significant changes in energy metabolism in the liver, brain and gills (Laiz-Carrión et al., 2002). In our study, we correlated cortisol treatment with increases in plasma glucose levels until day 3 and plasma lactate levels between days 3 and 10 post-injection, suggesting that the increased energy requirements due to high cortisol levels are fulfilled first by glucose and subsequently by lactate (Soengas et al., 2007). In addition, the high plasma glucose (but not lactate) levels observed in the control group during the first $24 \mathrm{~h}$ post-injection indicate a minor stress response to handling, which could activate specific regulatory pathways (see below).

\section{Regulation of AVT and IT synthesis and release}

The pituitary levels of AVT and IT represent the stored fraction of nonapeptides synthesised within neurons of the various hypothalamic nuclei (e.g. preoptic and lateral tuberal nuclei). Plasma AVT and IT levels represent a balance between hormonal
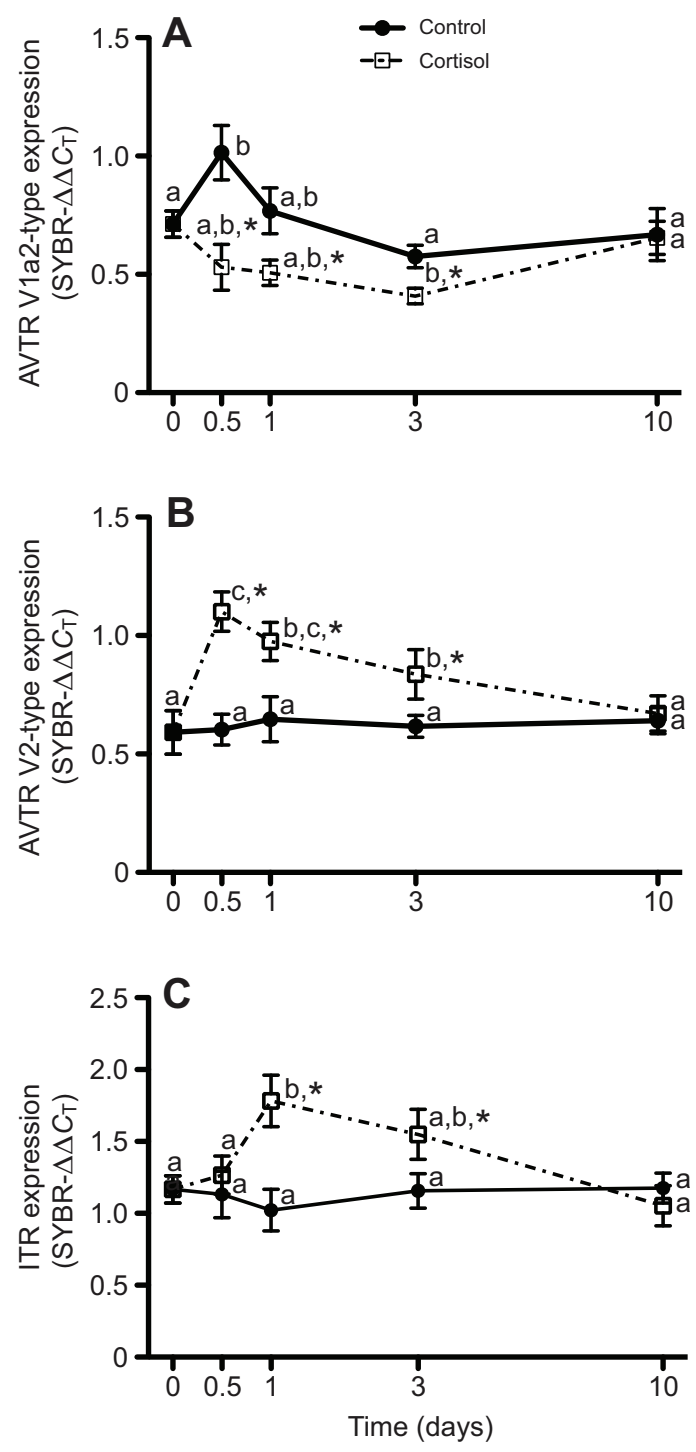

Fig. 5. Time course of changes in hypothalamic AVT and IT receptor mRNA expression levels in S. aurata specimens implanted i.p. with $5 \mathrm{\mu l} \mathrm{g}^{-1}$ body mass of coconut oil alone (control) or with cortisol (50 $\mathbf{~ g ~ g ~}^{-1}$ body mass). Receptors are AVTR V1a2-type (A), AVTR V2-type (B) and ITR (C). For further details, see the legend of Fig. 1.

secretion from the pituitary and a variety of removal processes, including renal clearance, enzymatic degradation and binding to receptors in various tissues (Goossens et al., 1977; van den Dungen et al., 1982; Acher, 1993; Acher and Chauvet, 1995; Goodson and Bass, 2000).

AVT, along with other neuropeptides, stimulates the secretion of pituitary ACTH (Fryer et al., 1985; Baker et al., 1996) as well as plasma cortisol in fish subjected to stressful situations (Fryer and Leung, 1982). In $S$. aurata, plasma AVT and cortisol levels increase in specimens maintained at a high stocking density (Mancera et al., 2008). Furthermore, AVT treatment causes higher plasma cortisol concentrations and induces a number of metabolic changes in this species (Sangiao-Alvarellos et al., 2006). In our experiment, the cortisol-treated group showed progressive increases in pituitary AVT and IT levels as a result of higher hypothalamic pro-VT and pro-IT expression during the first $24 \mathrm{~h}$ (Figs 2 and 3). The increase in plasma IT concentration between 12 and $24 \mathrm{~h}$ post-injection (Fig. 4B) could indicate that cortisol activates pituitary secretion to 

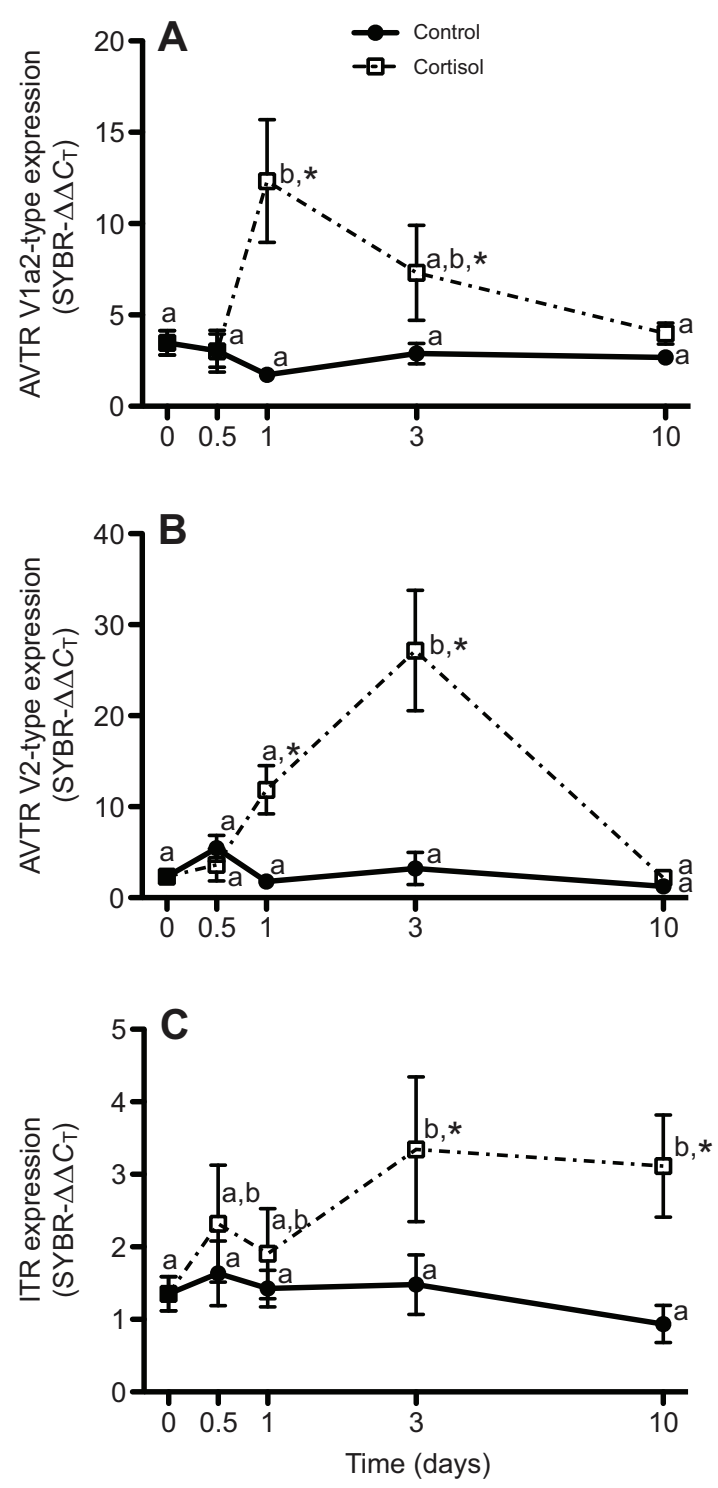

Fig. 6. Time course of changes in hepatic AVT and IT receptor mRNA expression levels in $S$. aurata specimens implanted i.p. with $5 \mu \mathrm{g} \mathrm{g}^{-1}$ body mass of coconut oil alone (control) or with cortisol $\left(50 \mu \mathrm{g} \mathrm{g}^{-1}\right.$ body mass). Receptors are AVTR V1a2-type (A), AVTR V2-type (B) and ITR (C). For further details, see the legend of Fig. 1.

modulate physiological functions in the periphery, although interactions between the isotocinergic and stress pathways have not been well characterised. However, the decrease in plasma AVT concentration, together with the activation of pro-VT mRNA expression (Fig. 4A), suggests that AVT secreted from the pituitary is binding to specific receptors. This finding suggests that AVT production is being used to stimulate metabolism and provide fuel within the CNS, at least in part, for neurotransmitter synthesis and for neuronal or glial activity (Sangiao-Alvarellos et al., 2004). Taken together, these findings demonstrate a clear connection between these two endocrine systems in the context of this physiological challenge.

The increases in plasma AVT and IT levels observed in the control group at $12 \mathrm{~h}$ post-injection were probably due to acute stress caused by the handling process (Fig. 4), during which time endogenous cortisol production increased slightly (but not significantly) along with an increase in plasma glucose levels.
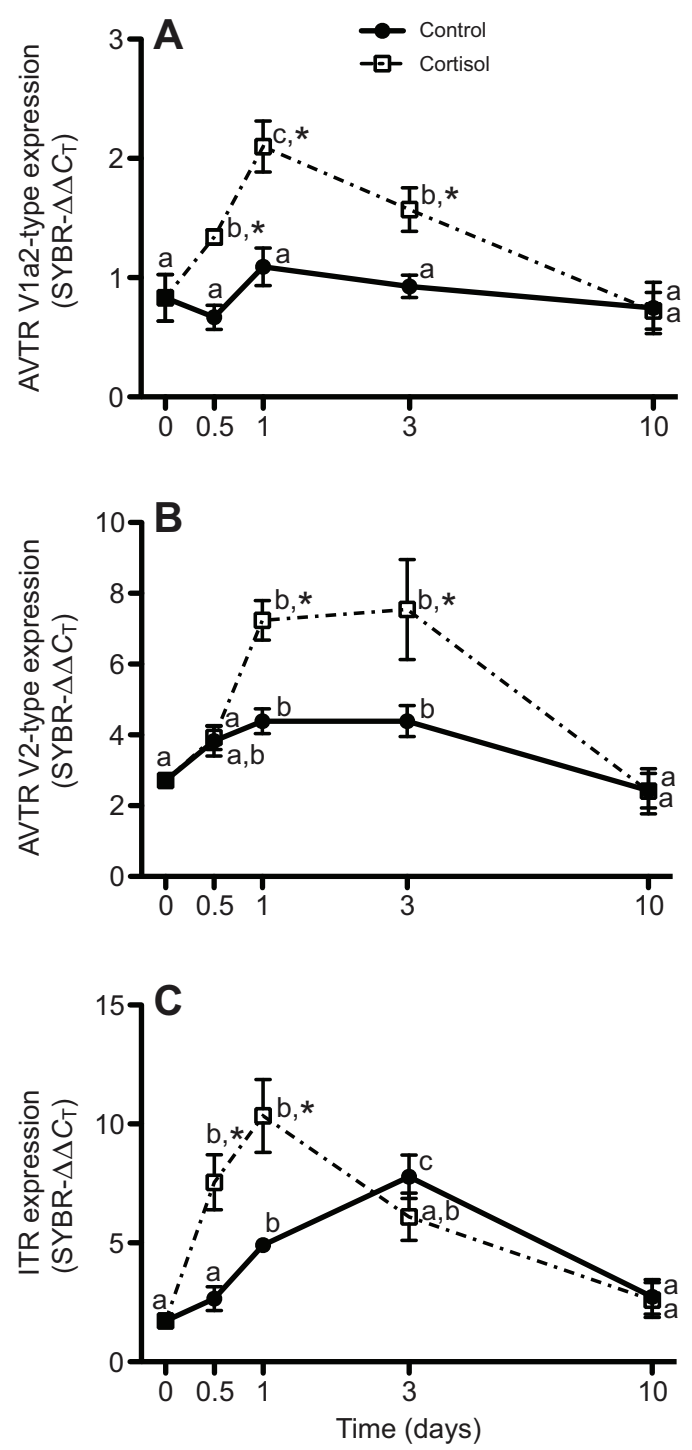

Fig. 7. Time course of changes in branchial AVT and IT receptor mRNA expression levels in $S$. aurata specimens implanted i.p. with $5 \mu \mathrm{g} \mathrm{g}^{-1}$ body mass of coconut oil alone (control) or with cortisol $\left(50 \mathrm{\mu g} \mathrm{g}^{-1}\right.$ body mass). Receptors are AVTR V1a2-type (A), AVTR V2-type (B) and ITR (C). For further details, see the legend of Fig. 1.

\section{Expression of the AVT and IT receptor genes following cortisol treatment}

Based on mammalian models, three AVP receptors (AVPRs) have been described with specific and well-established tissue distributions (Mahlmann et al., 1994; Warne, 2001). However, in most fish species, the AVTR sub-types are more ubiquitously distributed (Konno et al., 2009; Lema, 2010), including in the gilthead sea bream (Martos-Sitcha et al., 2014a). The presence of these receptors in a variety of tissues, such as the brain, liver, gills and head kidney, has previously been demonstrated while assessing the effects of AVT and IT administration or even analysing its mRNA expression (e.g. Motais and Maetz, 1967; Henderson and Wales, 1974; Guibbolini et al., 1988; Guibbolini et al., 2000; Amer and Brown, 1995; Conklin et al., 1996; Konno et al., 2009; Konno et al., 2010; Lema, 2010; Martos-Sitcha et al., 2014a), suggesting that physiological processes within these tissues are regulated by the vasotocinergic and/or isotocinergic systems. Interestingly, our results 

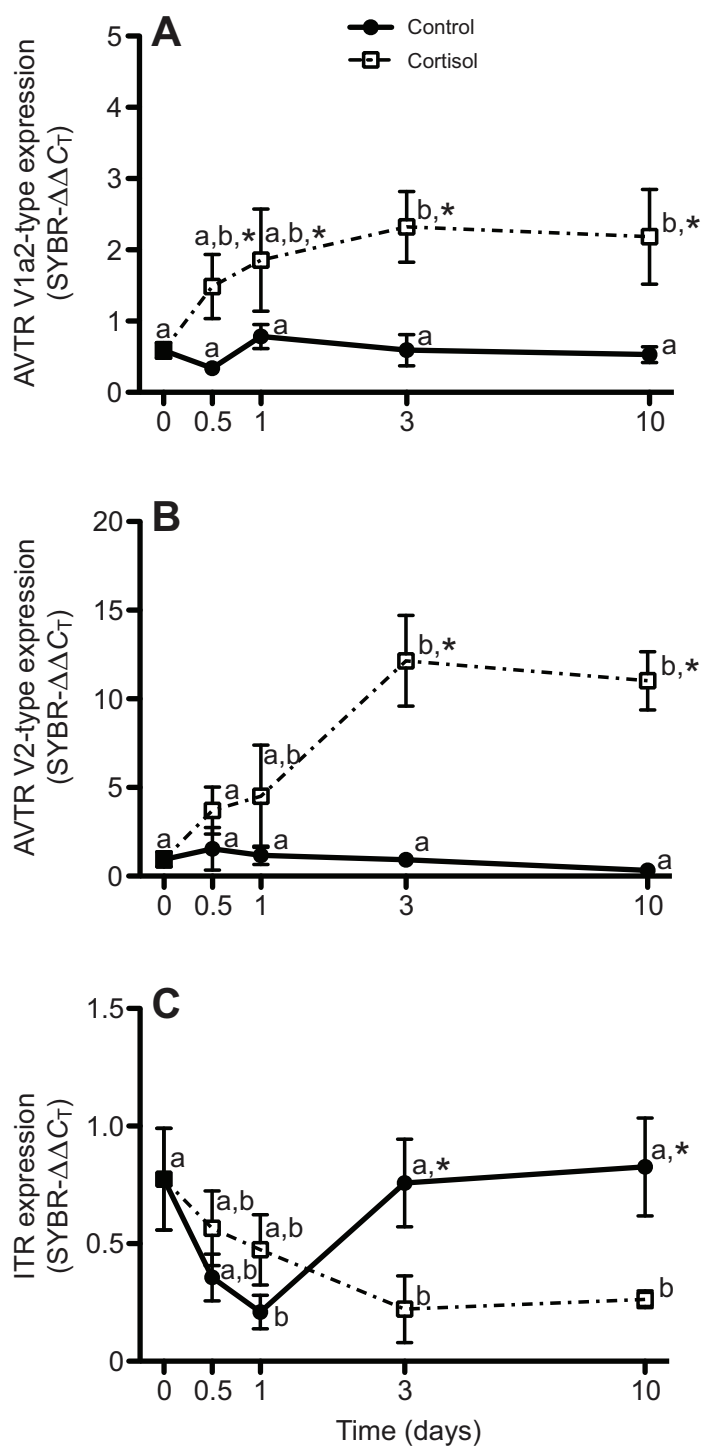

Fig. 8. Time course of changes in head kidney AVT and IT receptor mRNA expression levels in $S$. aurata specimens implanted i.p. with $5 \mu \mathrm{g}^{-1}$ body mass of coconut oil alone (control) or with cortisol ( $50 \mathrm{\mu g} \mathrm{g}^{-1}$ body mass). Receptors are AVTR V1a2-type (A), AVTR V2-type (B) and ITR (C). For further details, see the legend of Fig. 1.

show that increased mRNA expression of the three receptors following cortisol injection is concurrent with decreased plasma levels of the AVT and IT hormones, suggesting that active nonapeptides in the bloodstream are being removed by binding to specific receptors in the target tissues. Indeed, this phenomenon has been observed in this species following salinity transfers (Kleszczyńska et al., 2006; Martos-Sitcha et al., 2013b; MartosSitcha et al., 2014a).

\section{Hypothalamus}

In several teleost species, including $S$. aurata, significant changes in brain metabolism and endocrine pathways have previously been reported in specimens subjected to various types of stress (Soengas and Aldegunde, 2002; Sangiao-Alvarellos et al., 2003a; SangiaoAlvarellos et al., 2003b; Laiz-Carrión et al., 2002; Laiz-Carrión et al., 2003; Laiz-Carrión et al., 2005; Polakof et al., 2006), and AVT and/or IT have been proposed as putative endocrine regulatory molecules that may be involved in these changes (SangiaoAlvarellos et al., 2004; Sangiao-Alvarellos et al., 2006; MartosSitcha, 2013b; Martos-Sitcha et al., 2014a; Gesto et al., 2014).

In contrast to the upregulation observed in the control group, where handling requires the activation of metabolic pathways via cortisol, the observed downregulation of AVTR V1a2-type expression in the hypothalamus following cortisol treatment supports a role for AVT in the hypothalamic-pituitary-interrenal (HPI) axis, specifically in the stimulation of ACTH cells (Batten et al., 1990; Wendelaar Bonga, 1997). Therefore, these data strongly suggest that the stress axis can be controlled not only by canonical hormones/factors, such as corticotropin-releasing hormone (CRH) and thyrotropin-releasing hormone (TRH), but also by AVT through the V1-type receptor. In addition, the AVTR V1-type is known to be present in the anterior pituitary (Antoni, 1984) where ACTH cells are located, at least according to mammalian models. However, the lack of change in AVTR levels following salinity challenges in $S$. aurata (Martos-Sitcha et al., 2014a) suggests that activation of these pathways is species specific and dependent on the type of stressor being applied.

Furthermore, increased mRNA expression levels for both AVTR V2-type and ITR were only observed in the cortisol-treated group (Fig. 5B,C), indicating that expression of these receptors is enhanced in response to stress, which involves metabolic changes in the brain (Soengas and Aldegunde, 2002; Sangiao-Alvarellos et al., 2004; Sangiao-Alvarellos et al., 2006). The correlation between expression of the hypothalamic precursor molecules (pro-VT and pro-IT) and their receptors (AVTR V2-type and ITR) suggests a role for these receptors in the activation of the AVT and IT systems during stressrelated processes. This correlation has previously been demonstrated for the V2-type receptor in sea bream specimens exposed to environmental salinity stressors (Martos-Sitcha et al., 2014a). However, to the best of our knowledge, this is the first study demonstrating a potential link between the stress and isotocinergic pathways at the hypothalamic level, and therefore we cannot make a comparative study regarding this issue. To summarise, our results strongly suggest that both vasotocinergic and isotocinergic systems could be important players, at the hypothalamic level, in the regulation of the metabolic pathways previously demonstrated after cortisol treatment (Laiz-Carrión et al., 2002; Laiz-Carrión et al., 2003). However, additional experiments involving not only other kinds of stressor but also the mechanism involved in this regulation will be necessary for a better understanding of the proper function of AVT and IT in the control of the energy supply required in the brain.

\section{Liver}

In $S$. aurata, it was previously shown that AVT injection and subsequent transfer to environmental conditions of extreme salinity, which is considered to be stressful for this species, induced changes in hepatic metabolism (Sangiao-Alvarellos et al., 2006). Furthermore, it is known that glycogenolysis is stimulated in amphibian hepatocytes by AVT (Janssens et al., 1983; Ade et al., 1995) and in mammalian hepatocytes by AVP (Smith et al., 2003).

The increased levels of gene expression for the three tested receptors (AVTR V1a2-type, AVTR V2-type and ITR) (Fig. 6) suggest roles for both vasotocinergic and isotocinergic pathways in the stress response, requiring the activation of important metabolic tissues via exogenous/endogenous cortisol to increase energy supplies to the whole organism (Mommsen et al., 1999; LaizCarrión et al., 2002; Laiz-Carrión et al., 2003). Therefore, one might expect stimulation and regulation of gluconeogenesis, 
glycogenolysis and glycolysis (among other processes) in the liver following salinity-induced stress, as was recently suggested by Martos-Sitcha et al. (Martos-Sitcha et al., 2014a). In this study, the sequential activation of gene expression for the tested receptors was noteworthy. In fact, considering the changes we observed in receptor gene expression, as well as the various temporal expression patterns for certain primary metabolic enzymes and plasma metabolites during the interval following cortisol injection (Laiz-Carrión et al., 2003) (present results), we propose that the two AVT and the IT receptors may perform distinct functions by regulating separate metabolic enzymes in the liver: with an initial regulation by AVTR V1a2-type, a later regulation by AVTR V2-type and a final round of regulation by ITR.

\section{Gill}

In $S$. aurata, it has been demonstrated that AVT has regulatory effects on several molecular components of chloride cells, including the $\mathrm{Na}^{+} / \mathrm{K}^{+}$-ATPase pump (NKA), the cystic fibrosis transmembrane conductance regulator (CFTR) and the apical co-transporter $\mathrm{Na}^{+} / \mathrm{K}^{+} / 2 \mathrm{Cl}^{-}$(NKCC2), with the intracellular pathways of these receptors and ion transporters being shared (Martos-Sitcha et al., 2013a; Martos-Sitcha et al., 2014a). In fact, the development and proliferation of chloride cells, the increased NKA activity observed in several teleosts (McCormick, 1995; McCormick, 2012; Mancera et al., 2002; Laiz-Carrión et al., 2003) and the phenomenon of chloride secretion during episodes of chronic stress (Guibbolini et al., 1988; Martos-Sitcha et al., 2014a) support these conclusions. Moreover, cortisol facilitates adaptation to high salinity environments, where the antidiuretic activity of AVT is necessary.

The results presented in this work suggest, for the first time, the involvement of the vasotocinergic and isotocinergic systems in the stress response within gills. The pattern of changes in plasma AVT and IT levels (see above), as well as expression of the AVT and IT receptors within the gill (Fig. 7), suggests that stimulation of the vasotocinergic and isotocinergic systems could be important for increasing sodium and chloride secretion during the initial stress period, which has previously been described in Carassius auratus (Maetz et al., 1964) and following hormonal administration to gill respiratory cell culture in Dicentrarchus labrax (Guibbolini and Avella, 2003).

In addition to the clear effects of AVT and IT on osmoregulatory processes, it cannot be ruled out that these nonapeptides are stimulating metabolism within the gill to ensure a sufficient fuel supply. Considering both treatment groups - oil injection with (cortisol group) and without (control group) cortisol - the observed increases in AVTR and ITR expression during the first 3 days postinjection along with the characteristic plasma patterns clearly suggest the regulation of metabolic pathways by the stress process. Furthermore, the known role of cortisol in the energy metabolism of the gill suggests that this tissue undergoes metabolic changes and increased hypo-osmoregulatory capacity in response to this hormone (Laiz-Carrión et al., 2002). However, further studies will be necessary to test this hypothesis.

\section{Head kidney}

To the best of our knowledge, this is the first time that variations in the expression of AVTRs and ITR in response to cortisol treatment have been reported in the head kidney. The observation of increased mRNA expression levels for the AVTR genes in this interrenal tissue suggests that AVT can directly affect cortisol production. However, data from the cortisol-treated group suggest a potential role for IT in controlling the synthesis of cortisol at the interrenal tissue level, inducing a negative feedback process via the ITR mediated by the higher cortisol levels observed in the experimental group. Regardless, because of the presence of both interrenal and chromaffin cells within the interrenal tissue, we do not know the exact cell type on which the receptors are located. Therefore, other methodological approaches will be needed to elucidate whether AVTRs and/or ITR are involved in the stress pathway through the regulation of cortisol synthesis and release via AVT and/or IT in this tissue, and also to reveal whether this regulation could be carried out as a result of their presence in the same cells where catecholamines and cortisol are produced.

In summary, this study demonstrates that there are dynamic changes to the vasotocinergic and isotocinergic systems following i.p. administration of cortisol using coconut oil implants. Analysis of these systems, from pro-peptide expression to the putative effects of their specific receptors (AVTR type V1a2, AVTR type V2 and ITR), reveals distinct physiological processes at work within the various organs we analysed, including changes to metabolism, ion regulation and the stress response, all of which respond to cortisol. These results, taken together with previous findings on osmolality and metabolism, suggest cooperation between the stress pathway and the vasotocinergic and isotocinergic systems in $S$. aurata. However, further studies will be needed to better understand the relationships between these systems under various stress conditions.

\section{MATERIALS AND METHODS}

\section{Animals and experimental protocol}

Immature male gilthead sea bream specimens $(S$. aurata, $203.61 \pm 2.95 \mathrm{~g}$ body mass, $N=80$ ) were provided by Servicio Central de Investigación de Cultivos Marinos (SCI-CM, CASEM, University of Cádiz, Puerto Real, Cádiz, Spain; Operational Code REGA ES11028000312). Fish were transferred to the wet laboratories at the Faculty of Marine and Environmental Sciences (Puerto Real, Cádiz, Spain), where they were acclimated for 10 days in seawater (SW, 38\% salinity). Fish were randomly distributed between four, 10001 tanks ( $4 \mathrm{~kg} \mathrm{~m}^{-3}$ density; two tanks for each experimental condition) in an open system circuit under a natural photoperiod (in March 2012) for our latitude $\left(36^{\circ} 31^{\prime} 44^{\prime \prime} \mathrm{N}\right)$ and constant temperature $\left(18-19^{\circ} \mathrm{C}\right)$. Fish were fed a daily ration of $1 \%$ of their body mass of commercial pellets (Dibaq-Dibroteg S.A., Segovia, Spain). The fish were food deprived for $24 \mathrm{~h}$ prior to sampling.

On day 0 , fish were lightly anaesthetised with 2-phenoxyethanol $\left(0.5 \mathrm{ml} \mathrm{l}^{-1} \mathrm{SW}\right)$, weighed and implanted i.p. with vegetable oil (5:1 mixture of coconut:seed oils) alone (control, $N=36$ ) or with cortisol $\left(50 \mu \mathrm{g} \mathrm{g}^{-1}\right.$ body mass, $N=36$; hydrocortisone 21-hemisuccinate sodium salt; Sigma-Aldrich, Madrid, Spain; cat. no. H2270). Then, at $12 \mathrm{~h}$ and 1,3 and 10 days postinjection, nine fish from each experimental condition were anaesthetised with 2-phenoxyethanol $\left(1 \mathrm{ml} \mathrm{l}^{-1} \mathrm{SW}\right)$, weighed and then sampled. Blood samples were collected from the caudal peduncle in $1 \mathrm{ml}$ ammoniaheparinised (Sigma) syringes, and centrifuged ( $3 \mathrm{~min}$ at $10,000 \mathrm{~g}$ ) to obtain plasma. The plasma was divided into two samples: a $1 \mathrm{ml}$ portion was used for AVT/IT analysis and the remainder was used for cortisol, osmolality and metabolite measurements. The liver (for metabolite analysis) and pituitary were snap-frozen in liquid nitrogen and stored at $-80^{\circ} \mathrm{C}$ until further analysis. Biopsy samples $(\sim 30 \mathrm{mg})$ taken from the gills, head kidney and liver, as well as the complete hypothalamus, were placed in microfuge tubes containing $600 \mu \mathrm{l}$ RNAlater ${ }^{\mathcal{O}}$ (Life Technologies). The uninjected group $(N=8)$ was sampled on day 0 as an additional control. No mortality was observed in any of the groups during the experiment. All experiments were performed according to the Guidelines of the European Union (2010/63/UE) and Spanish legislation (RD 1201/2005 and law 32/2007) regarding the use of laboratory animals.

\section{Plasma parameters}

Plasma osmolality was measured by analysing $10 \mu \mathrm{l}$ of each individual sample with a pressure osmometer (Fiske One-Ten Osmometer, Fiske-VT, 
Table 2. Specific primers used for the semi-quantitative QPCR expression analysis and size of the amplified products

\begin{tabular}{|c|c|c|c|}
\hline Primer & Nucleotide sequence & Primer concentration $\left(\mathrm{nmol} \mathrm{I}^{-1}\right)$ & Amplicon size (bp) \\
\hline qPCR-pro- $V_{F}$ & 5'-AGAGGCTGGGATCAGACAGTGC-3' & 200 & 129 \\
\hline qPCR-pro-V $T_{R}$ & 5'-TCCACACAGTGAGCTGTTTCCG-3' & & \\
\hline qPCR-pro-IT $F$ & 5'-GGAGATGACCAAAGCAGCCA-3' & 200 & 151 \\
\hline qPCR-pro-IT $R$ & 5'-CAACCATGTGAACTACGACT-3' & & \\
\hline qPCR-AVTR-V $1_{F}$ & 5'-GACAGCCGCAAGTGATCAAG-3 & 400 & 203 \\
\hline qPCR-AVTR-V $1_{R}$ & 5'-CCCGACCGCACACCCCCTGGCT-3' & & \\
\hline qPCR-AVTR-V2 & 5'-ATCACAGTCCTTGCATTGGTG-3' & 600 & 120 \\
\hline qPCR-AVTR-V $2_{R}$ & 5'-GCACAGGTTGACCATGAACAC-3' & & \\
\hline qPCR-ITR & 5'-GGAGGATCGTTTTAAAGACATGG-3' & 400 & 120 \\
\hline qPCR-ITR $R_{R}$ & 5'-TGTTGTCTCCСTGTCAGATTTTC-3' & & \\
\hline qPCR $\beta$-actin ${ }_{\mathrm{Fw}}$ & 5'-TCTTCCAGCCATCCTTCCTCG-3 & 200 & 108 \\
\hline qPCR $\beta-$ actin $_{\mathrm{Rv}}$ & 5'-TGTTGGCATACAGGTCCTTACGG-3' & & \\
\hline
\end{tabular}

USA), and values are expressed as $\mathrm{mOsm} \mathrm{kg}^{-1}$. Glucose and lactate concentrations were measured using commercial kits from Spinreact (Barcelona, Spain; glucose-HK ref. 1001200; lactate ref. 1001330) adapted to 96-well microplates. All assays were run on an Automated Microplate Reader (PowerWave 340, BioTek Instrument Inc., Winooski, VT, USA) controlled using $\mathrm{KCjunior}^{\mathrm{TM}}$ software. Standards and samples were measured in duplicate.

Plasma cortisol levels were measured using enzyme-linked immunosorbent assays (ELISAs) performed in microtitre plates (MaxiSorp ${ }^{\mathrm{TM}}$, Nunc, Roskilde, Denmark), as previously described for this species (Martos-Sitcha et al., 2014b). Steroids were extracted from $5 \mu \mathrm{l}$ plasma in $100 \mu \mathrm{l} \mathrm{RB}[10 \% \mathrm{v} / \mathrm{v}$ potassium phosphate buffer (PPB) $1 \mathrm{~mol}^{-1}, 0.01 \% \mathrm{w} / \mathrm{v} \mathrm{NaN}, 2.34 \% \mathrm{w} / \mathrm{v}$ $\mathrm{NaCl}, 0.037 \% \mathrm{w} / \mathrm{v}$ EDTA and $0.1 \% \mathrm{w} / \mathrm{v} \mathrm{BSA}]$ and $1.2 \mathrm{ml}$ methanol (Panreac), which was then allowed to evaporate over $48-72 \mathrm{~h}$ at $37^{\circ} \mathrm{C}$. A cortisol EIA standard (cat. no. 10005273), a goat anti-mouse IgG monoclonal antibody (cat. no. 400002), a specific cortisol express EIA monoclonal antibody (cat. no. 400372) and a specific cortisol express AChE tracer (cat. no. 400370) were obtained from Cayman Chemical Company (MI, USA). Standards and extracted plasma samples were analysed in duplicate. A standard curve was constructed from $2.5 \mathrm{ng} \mathrm{ml}^{-1}$ to $9.77 \mathrm{pg} \mathrm{ml}^{-1}\left(R^{2}=0.992\right)$. The lower limit of detection (98.75\% of binding, ED98.75) was $10.07 \mathrm{pg} \mathrm{ml}^{-1}$. The percentage of recovery was $95 \%$. The inter- and intra-assay coefficients of variation (calculated from sample duplicates) were $0.49 \pm 0.28 \%$ and $4.09 \pm 0.85 \%$, respectively. The cross-reactivity of the specific antibody towards intermediate steroid synthesis products was determined by the supplier (Cayman Chemical Company).

\section{Quantification of mRNA expression levels (qPCR)}

The manufacturer's instructions were followed unless otherwise stated. Total RNA was extracted from the complete hypothalamus using Ultra-Turrax ${ }^{\circledR}$ T8 (IKA ${ }^{\circledR}$-Werke) or from the gill, head kidney and liver biopsies using the NucleoSpin ${ }^{\circledR}$ RNAII kit (Macherey-Nagel). Genomic DNA (gDNA) was removed via on-column DNase digestion at $37^{\circ} \mathrm{C}$ for 30 min using rDNase (RNase-free) included in the kit. RNA quality was assessed using a Bioanalyzer 2100 and with the RNA 6000 Nano kit (Agilent Technologies). RNA quantity was measured by spectrophotometry at $260 \mathrm{~nm}$ using a BioPhotometer Plus (Eppendorf). Only samples with an RNA integrity number (RIN) greater than 8.50 were tested using real-time quantitative PCR (qPCR). Primer oligonucleotide sequences and the final concentrations used in the QPCR reactions are shown in Table 2 and were as described previously (Martos-Sitcha et al., 2013b; Martos-Sitcha et al., 2014a). Each reaction mixture $(10 \mu \mathrm{l})$ contained $0.5 \mu \mathrm{l}$ each specific forward and reverse primer, and $5 \mu 1$ PerfeCTa SYBR ${ }^{\circledR}$ Green FastMix ${ }^{\mathrm{TM}}$ (Quanta Biosciences). Reactions were conducted in semi-skirted twin.tec 96-well real-time PCR plates (Eppendorf) covered with adhesive Masterclear real-time PCR Film (Eppendorf). The thermocycling procedures were as previously described by Martos-Sitcha et al. (Martos-Sitcha et al., 2013b; Martos-Sitcha et al., 2014a). Melting curves were used to ensure that only a single PCR product was amplified and to verify the absence of primer-dimer artefacts. Each sample was run in triplicate. The results were normalised to $\beta$-actin levels because of its low variability (less than $0.35 C_{\mathrm{T}}$ in each tissue) under our experimental conditions. Relative gene quantification was performed using the $\Delta \Delta C_{\mathrm{T}}$ method (Livak and Schmittgen, 2001) with mRNA from the hypothalamus of the control group on day 0 as a reference (inter-assay coefficient of variation for $\beta$-actin in all samples/plates $=0.37 \pm 0.08 \%$ ).

\section{AVT and IT levels in the plasma and pituitary}

AVT and IT levels in the plasma and pituitary gland were determined using high-performance liquid chromatography (HPLC) with fluorescence detection preceded by solid-phase extraction (SPE), based on previous studies (Gozdowska et al., 2006; Martos-Sitcha et al., 2013b). Plasma samples $(1 \mathrm{ml})$ were acidified with $1 \mathrm{~mol} \mathrm{l}^{-1} \mathrm{HCl}(100 \mu \mathrm{l})$ and centrifuged at $6000 \mathrm{~g}$ for $20 \mathrm{~min}$ at $4^{\circ} \mathrm{C}$. Frozen pituitaries were weighed $(452.75 \pm 17.59 \mu \mathrm{g})$ and sonicated in $0.5 \mathrm{ml}$ Milli-Q water (Microson ${ }^{\mathrm{TM}} \mathrm{XL}$, Misonix, Farmingdale, NY, USA). Next, glacial acetic acid (1.25 $\mu$ l) was added, and the samples were placed in a boiling water bath for $3.5 \mathrm{~min}$. The extracts were cooled down and then centrifuged at $6000 \mathrm{~g}$ for $15 \mathrm{~min}$ at $4^{\circ} \mathrm{C}$. Then, the supernatants were loaded onto previously conditioned $(1 \mathrm{ml}$ methanol, $1 \mathrm{ml}$ water $)$ SPE columns $\left(30 \mathrm{mg} \mathrm{ml}^{-1}\right.$, STRATA-X, Phenomenex). First water ( $600 \mu \mathrm{l})$ then $0.1 \%$ TFA (trifluoroacetic acid) in $5 \%$ acetonitrile $(600 \mu \mathrm{l})$ was passed through the columns to wash away impurities. The peptides were eluted with $2 \times 600 \mu 180 \%$ acetonitrile. The eluate was evaporated to dryness using a Turbo Vap LV Evaporator (Caliper Life Sciences, USA). Samples were then frozen and stored at $-80^{\circ} \mathrm{C}$ until HPLC analysis. Before quantitative analysis, the samples were resuspended in $40 \mu 10.1 \%$ TFA and then divided into two portions for duplicate analysis. Pre-column derivatisation of IT and AVT in each of the $20 \mu 1$ samples was performed using $3 \mu \mathrm{l}$ NBD-F (4-fluoro-7-nitro-2,1,3-benzoxadiazole) solution (30 mg NBD-F in $1 \mathrm{ml}$ of acetonitrile) in a mixture of $20 \mu \mathrm{l}$ phosphoric buffer $\left(0.2 \mathrm{~mol} \mathrm{l}^{-1}, \mathrm{pH} 9.0\right)$ and $20 \mu \mathrm{l}$ acetonitrile. The solution was heated to $60^{\circ} \mathrm{C}$ for $3 \mathrm{~min}$ in a dry heating block and cooled down on ice. Next, $4 \mu \mathrm{l}$ of $1 \mathrm{~mol} \mathrm{l}^{-1} \mathrm{HCl}$ was added. Derivatised samples were measured using an Agilent 1200 Series Quaternary HPLC System (Agilent Technologies, USA). Chromatographic separation was achieved using Agilent ZORBAX Eclipse XDB-C18 columns $(150 \mathrm{~mm} \times 4.6 \mathrm{~mm}$ i.d., $5 \mu \mathrm{m}$ particle size). A gradient elution system was used to separate the derivatised peptides. The mobile phase consisted of solvent $\mathrm{A}\left(0.1 \%\right.$ TFA in $\left.\mathrm{H}_{2} \mathrm{O}\right)$ and solvent B $\left(0.1 \%\right.$ TFA in acetonitrile: $\left.\mathrm{H}_{2} \mathrm{O}, 3: 1\right)$. A linear gradient was $45-70 \%$ eluent $\mathrm{B}$ in $20 \mathrm{~min}$. Flow rate was set at $1 \mathrm{ml} \mathrm{min}^{-1}$ and the column temperature at $20^{\circ} \mathrm{C}$. The injection volume was $67 \mu \mathrm{l}$. Fluorescence detection was carried out at $530 \mathrm{~nm}$ with excitation at $470 \mathrm{~nm}$.

\section{Statistics}

Differences were evaluated using two-way ANOVA with treatment (control or $50 \mu \mathrm{g}$ cortisol g ${ }^{-1}$ body mass) and time course (day $0,12 \mathrm{~h}$, and days 1,3 and 10) as the main factors, followed by post hoc comparisons with Tukey's test, as appropriate. All tests were performed using GraphPad Prism ${ }^{\circledR}$ (v.5.0b) software. Differences were considered significant at $P<0.05$.

\section{Acknowledgements}

The authors wish to thank Servicio Central de Investigación de Cultivos Marinos (SCI-CM, CASEM, University of Cádiz, Puerto Real, Cádiz, Spain) for providing experimental fish, and Mrs María Francisca Osta and Mr Juan José Blanco for 
their excellent technical assistance. The experiments were carried out at the Campus de Excelencia Internacional del Mar (CEI-MAR) at two separate locations (University of Cádiz and ICMAN-CSIC).

\section{Competing interests}

The authors declare no competing or financial interests.

\section{Author contributions}

L.C. and J.R.-P. conceived the study and experimental design, carried out acquisition, statistical analysis and interpretation of the data, and drafted the manuscript; M.G. analysed the nonapeptides using HPLC techniques; E.K. provided technical and material support for nonapeptide analysis, critically reviewed the manuscript and provided partial funding; G.M.-R., J.M.M. and J.A.M.S. conceived the study and experimental design, supervised the study, contributed key concepts for important physiological, molecular biology and endocrine components, and obtained funding. All authors contributed to the writing of the manuscript.

\section{Funding}

This study was funded by project AGL2010-14876 from the Ministry of Science and Innovation to J.M.M. (Spain) and by project 498/N-HISZP-JPR/2009/0 to E.K (Poland).

\section{References}

Acher, R. (1993). Neurohypophysial peptide systems: processing machinery, hydroosmotic regulation, adaptation and evolution. Regul. Pept. 45, 1-13

Acher, R. and Chauvet, J. (1995). The neurohypophysial endocrine regulatory cascade: precursors, mediators, receptors, and effectors. Front. Neuroendocrinol. 16, 237-289.

Ade, T., Segner, H. and Hanke, W. (1995). Hormonal response of primary hepatocytes of the clawed toad, Xenopus laevis. Exp. Clin. Endocrinol. Diabetes 103, 21-27.

Almeida, O., Gozdowska, M., Kulczykowska, E. and Oliveira, R. F. (2012). Brain levels of arginine-vasotocin and isotocin in dominant and subordinate males of a cichlid fish. Horm. Behav. 61, 212-217.

Amer, S. and Brown, J. A. (1995). Glomerular actions of arginine vasotocin in the in situ perfused trout kidney. Am. J. Physiol. 269, R775-R780.

Antoni, F. A. (1984). Novel ligand specificity of pituitary vasopressin receptors in the rat. Neuroendocrinology 39, 186-188.

Arias, A. (1976). Sobre la biología de la dorada, Sparus aurata L., de los Esteros de la Provincia de Cádiz. Investig. Pesq. 40, 201-222.

Baker, B. I., Bird, D. J. and Buckingham, J. C. (1996). In the trout, CRH and AVT synergize to stimulate ACTH release. Regul. Pept. 67, 207-210.

Balment, R. J., Lu, W., Weybourne, E. and Warne, J. M. (2006). Arginine vasotocin a key hormone in fish physiology and behaviour: a review with insights from mammalian models. Gen. Comp. Endocrinol 147, 9-16.

Batten, T. F. C., Cambre, M. L., Moons, L. and Vandesande, F. (1990). Comparative distribution of neuropeptide-immunoreactive systems in the brain of the green molly, Poecilia latipinna. J. Comp. Neurol. 302, 893-919.

Conklin, D. J., Mick, N. W. and Olson, K. R. (1996). Arginine vasotocin relaxation of gar (Lepisosteous spp.) hepatic vein in vitro. Gen. Comp. Endocrinol. 104, 52-60.

Fryer, J. N. and Leung, E. (1982). Neurohypophysial hormonal control of cortiso secretion in the teleost Carassius auratus. Gen. Comp. Endocrinol. 48, 425-431.

Fryer, J., Lederis, K. and Rivier, J. (1985). ACTH-releasing activity of urotensin I and ovine CRF: interactions with arginine vasotocin, isotocin and arginine vasopressin. Regul. Pept. 11, 11-15

Gesto, M., Soengas, J. L., Rodríguez-Illamola, A. and Míguez, J. M. (2014). Arginine vasotocin treatment induces a stress response and exerts a potent anorexigenic effect in rainbow trout, Oncorhynchus mykiss. J. Neuroendocrinol. 26 , 89-99.

Goodson, J. L. and Bass, A. H. (2000). Vasotocin innervation and modulation of vocal-acoustic circuitry in the teleost Porichthys notatus. J. Comp. Neurol. 422, 363379.

Goossens, N., Dierickx, K. and Vandesande, F. (1977). Immunocytochemical localization of vasotocin and isotocin in the preopticohypophysial neurosecretory system of teleosts. Gen. Comp. Endocrinol. 32, 371-375.

Gozdowska, M., Kleszczyńska, A., Sokołowska, E. and Kulczykowska, E. (2006). Arginine vasotocin (AVT) and isotocin (IT) in fish brain: diurnal and seasonal variations. Comp. Biochem. Physiol. 143B, 330-334.

Guibbolini, M. E. and Avella, M. (2003). Neurohypophysial hormone regulation of $\mathrm{Cl}^{-}$ secretion: physiological evidence for $\mathrm{V} 1$-type receptors in sea bass gill respiratory cells in culture. J. Endocrinol. 176, 111-119.

Guibbolini, M. E., Henderson, I. W., Mosley, W. and Lahlou, B. (1988). Arginine vasotocin binding to isolated branchial cells of the eel: effect of salinity. J. Mol. Endocrinol. 1, 125-130.

Guibbolini, M. E., Pierson, P. M. and Lahlou, B. (2000). Neurohypophysial hormone receptors and second messengers in trout hepatocytes. J. Endocrinol. 167, 137-144.

Hausmann, H., Meyerhof, W., Zwiers, H., Lederis, K. and Richter, D. (1995). Teleost isotocin receptor: structure, functional expression, mRNA distribution and phylogeny. FEBS Lett. 370, 227-230.

Henderson, I. W. and Garland, H. O. (1980). The interrenal gland in piscis. Part 2. Physiology. In General, Comparative and Clinical Endocrinology of the Adrenal
Cortex (ed. I. Chester Jones and I. W. Henderson), pp. 473-523. New York, NY: Academy Press.

Henderson, I. W. and Wales, N. A. M. (1974). Renal diuresis and antidiuresis after injections of arginine vasotocin in the freshwater eel (Anguilla anguilla L.). J. Endocrinol. 61, 487-500.

Hylland, P., Milton, S., Pek, M., Nilsson, G. E. and Lutz, P. L. (1997). Brain $\mathrm{Na}^{+} / \mathrm{K}^{+}-$ ATPase activity in two anoxia tolerant vertebrates: crucian carp and freshwater turtle. Neurosci. Lett. 235, 89-92.

Janssens, P. A. and Lowrey, P. (1987). Hormonal regulation of hepatic glycogenolysis in the carp, Cyprinus carpio. Am. J. Physiol. 252, R653-R660.

Janssens, P. A., Caine, A. G. and Dixon, J. E. (1983). Hormonal control of glycogenolysis and the mechanism of action of adrenaline in amphibian liver in vitro. Gen. Comp. Endocrinol. 49, 477-484.

Kalamarz-Kubiak, H., Meiri-Ashkenazi, I., Kleszczyńska, A. and Rosenfeld, H. (2014). In vitro effect of cortisol and urotensin I on arginine vasotocin and isotocin secretion from pituitary cells of gilthead sea bream Sparus aurata. J. Fish Biol. 84 448-458.

Kleszczyńska, A., Vargas-Chacoff, L., Gozdowska, M., Kalamarz, H., MartínezRodríguez, G., Mancera, J. M. and Kulczykowska, E. (2006). Arginine vasotocin, isotocin and melatonin responses following acclimation of gilthead sea bream (Sparus aurata) to different environmental salinities. Comp. Biochem. Physiol. 145A, 268-273.

Kleszczyńska, A., Sokołowska, E. and Kulczykowska, E. (2012). Variation in brain arginine vasotocin (AVT) and isotocin (IT) levels with reproductive stage and social status in males of three-spined stickleback (Gasterosteus aculeatus). Gen. Comp. Endocrinol. 175, 290-296.

Konno, N., Hyodo, S., Yamaguchi, Y., Kaiya, H., Miyazato, M., Matsuda, K. and Uchiyama, M. (2009). African lungfish, Protopterus annectens, possess an arginine vasotocin receptor homologous to the tetrapod V2-type receptor. J. Exp. Biol. 212, 2183-2193.

Konno, N., Hyodo, S., Yamaguchi, Y., Matsuda, K. and Uchiyama, M. (2010). Vasotocin/V2-type receptor/aquaporin axis exists in African lungfish kidney but is functional only in terrestrial condition. Endocrinology 151, 1089-1096.

Kulczykowska, E. (2001). Responses of circulating arginine vasotocin, isotocin, and melatonin to osmotic and disturbance stress in rainbow trout (Oncorhynchus mykiss). Fish Physiol. Biochem. 24, 201-206.

Kulczykowska, E. (2007). Arginine vasotocin and isotocin: towards their role in fish osmoregulation. In Fish Osmoregulation (ed. B. Baldisserotto, J. M. Mancera Romero and B. G. Kapoor), pp. 151-176. Enfield, NH: Science Publisher

Laiz-Carrión, R., Sangiao-Alvarellos, S., Guzmán, J. M., Martin del Río, M. P. Míguez, J. M., Soengas, J. L. and Mancera, J. M. (2002). Energy metabolism in fish tissues related to osmoregulation and cortisol action. Fish Physiol. Biochem. 27, 179-188.

aiz-Carrión, R., Martín Del Río, M. P., Miguez, J. M., Mancera, J. M. and Soengas, J. L. (2003). Influence of cortisol on osmoregulation and energy metabolism in gilthead seabream Sparus aurata. J. Exp. Zool. A 298, 105-118.

Laiz-Carrión, R., Guerreiro, P. M., Fuentes, J., Canario, A. V. M., Martín Del Río, M. P. and Mancera, J. M. (2005). Branchial osmoregulatory response to salinity in the gilthead sea bream, Sparus auratus. J. Exp. Zool. A 303, 563-576.

Lema, S. C. (2010). Identification of multiple vasotocin receptor cDNAs in teleost fish: sequences, phylogenetic analysis, sites of expression, and regulation in the hypothalamus and gill in response to hyperosmotic challenge. Mol. Cell. Endocrinol. 321, 215-230.

Livak, K. J. and Schmittgen, T. D. (2001). Analysis of relative gene expression data using real-time quantitative PCR and the 2(-Delta Delta C(T)) Method. Methods 25, 402-408.

Maetz, J., Bourguet, J., Lahlough, B. and Hourdry, J. (1964). Neurohypophysial peptides and osmoregulation in Carassius auratus. Gen. Comp. Endocrinol. 4, 508522

Mahlmann, S., Meyerhof, W., Hausmann, H., Heierhorst, J., Schönrock, C., Zwiers, H., Lederis, K. and Richter, D. (1994). Structure, function, and phylogeny of [Arg8]vasotocin receptors from teleost fish and toad. Proc. Natl. Acad. Sci. USA 91, $1342-1345$

Mancera, J. M. and Fuentes, J. (2006). Osmoregulatory actions of hypophyseal hormones in teleosts. In Fish Endocrinology, Vol. 1. (ed. B. G. Kapoor, G. Zaccone and M. Reinecke), pp. 393-417. Enfield, NH: Science Publishers

Mancera, J. M. and McCormick, S. D. (2007). Role of prolactin, growth hormone, insuline-like growth factor I and cortisol in teleost osmoregulation In Fish Osmoregulation (ed. B. Baldisserotto, J. M. Mancera and B. G. Kapoor), pp. 497515. Enfield, NH: Science Publishers.

Mancera, J. M., Laiz Carrión, R. and del Pilar Martín del Río, M. (2002). Osmoregulatory action of PRL, GH, and cortisol in the gilthead seabream (Sparus aurata L). Gen. Comp. Endocrinol. 129, 95-103.

Mancera, J. M., Vargas-Chacoff, L., García-López, A., Kleszczyńska, A., Kalamarz, H., Martínez-Rodríguez, G. and Kulczykowska, E. (2008). High density and food deprivation affect arginine vasotocin, isotocin and melatonin in gilthead sea bream (Sparus auratus). Comp. Biochem. Physiol. 149A, 92-97.

Martos-Sitcha, J. A., Gregório, S. F., Carvalho, E. S. M., Canario, A. V. M., Power, D. M., Mancera, J. M., Martínez-Rodríguez, G. and Fuentes, J. (2013a). AVT is involved in the regulation of ion transport in the intestine of the sea bream (Sparus aurata). Gen. Comp. Endocrinol. 193, 221-228

Martos-Sitcha, J. A., Wunderink, Y. S., Gozdowska, M., Kulczykowska, E., Mancera, J. M. and Martínez-Rodríguez, G. (2013b). Vasotocinergic and isotocinergic systems in the gilthead sea bream (Sparus aurata): an osmoregulatory story. Comp. Biochem. Physiol. 166A, 571-581. 
Martos-Sitcha, J. A., Fuentes, J., Mancera, J. M. and Martínez-Rodríguez, G. (2014a). Variations in the expression of vasotocin and isotocin receptor genes in the gilthead sea bream Sparus aurata during different osmotic challenges. Gen. Comp. Endocrinol. 197, 5-17.

Martos-Sitcha, J. A., Wunderink, Y. S., Straatjes, J., Skrzynska, A. K., Mancera, J. M. and Martínez-Rodríguez, G. (2014b). Different stressors induce differential responses of the $\mathrm{CRH}$-stress system in the gilthead sea bream (Sparus aurata). Comp. Biochem. Physiol. 177A, 49-61.

McCormick, S. D. (1995). Hormonal control of gill $\mathrm{Na}^{+}, \mathrm{K}^{+}$-ATPase and chloride cell function. Fish Physiology 14, 285-315.

McCormick, S. D. (2012). Smolt physiology and endocrinology. Fish Physiol. 32, 199251.

Mommsen, T. P., Vijayan, M. M. and Moon, T. W. (1999). Cortisol in teleosts, dynamics, mechanisms of action, and metabolic regulation. Rev. Fish Biol. Fish. 9 , 211-268.

Moon, T. W. and Mommsen, T. P. (1990). Vasoactive peptides and phenylephrine actions in isolated teleost hepatocytes. Am. J. Physiol. 259, E644-E649.

Moons, L., Cambré, M., Batten, T. F. C. and Vandesande, F. (1989). Autoradiographic localization of binding sites for vasotocin in the brain and pituitary of the sea bass (Dicentrarchus labrax). Neurosci. Lett. 100, 11-16.

Motais, R. and Maetz, J. (1967). [Arginine vasotocin and development of branchial permeability to sodium during the passage of soft water and sea water in flounders]. J. Physiol. (Paris) 59 Suppl., 271.

Polakof, S., Arjona, F. J., Sangiao-Alvarellos, S., Martín del Río, M. P., Mancera, J. M. and Soengas, J. L. (2006). Food deprivation alters osmoregulatory and metabolic responses to salinity acclimation in gilthead sea bream Sparus auratus. J. Comp. Physiol. B 176, 441-452.

Purdon, A. D. and Rapoport, S. I. (1998). Energy requirements for two aspects of phospholipid metabolism in mammalian brain. Biochem. J. 335, 313-318.

Sangiao-Alvarellos, S., Bouça, P., Míguez, J. M. and Soengas, J. L. (2003a). Intracerebroventricular injections of noradrenaline affect brain energy metabolism of rainbow trout. Physiol. Biochem. Zool. 76, 663-671.

Sangiao-Alvarellos, S., Laiz-Carrión, R., Guzmán, J. M., Martin del Río, M. P. Miguez, J. M., Mancera, J. M. and Soengas, J. L. (2003b). Acclimation of S aurata to various salinities alters energy metabolism of osmoregulatory and nonosmoregulatory organs. Am. J. Physiol. 285, R897-R907.
Sangiao-Alvarellos, S., Lapido, M., Miguez, J. M. and Soengas, J. L. (2004). Effects of central administration of arginine vasotocin on monoaminergic neurotransmitters and energy metabolism of rainbow trout brain. J. Fish Biol. 64, 1313-1329.

Sangiao-Alvarellos, S., Arjona, F. J., Martín del Río, M. P., Míguez, J. M., Mancera, J. M. and Soengas, J. L. (2005). Time course of osmoregulatory and metabolic changes during osmotic acclimation in Sparus auratus. J. Exp. Biol. 208, 4291 4304.

Sangiao-Alvarellos, S., Polakof, S., Arjona, F. J., Kleszczyńska, A., Martín Del Río, M. P., Míguez, J. M., Soengas, J. L. and Mancera, J. M. (2006). Osmoregulatory and metabolic changes in the gilthead sea bream Sparus auratus after arginine vasotocin (AVT) treatment. Gen. Comp. Endocrinol. 148, 348-358.

Sherwani, F. A. and Parwez, I. (2008). Plasma thyroxine and cortisol profiles and gill and kidney $\mathrm{Na}^{+} / \mathrm{K}^{+}$-ATPase and SDH activities during acclimation of the catfish Heteropneustes fossilis (bloch) to higher salinity, with special reference to the effects of exogenous cortisol on hypo-osmoregulatory ability of the catfish. Zoolog. Sci. 25, 164-171.

Smith, R. F., French, N. P., Saphier, P. W., Lowry, P. J., Veldhuis, J. D. and Dobson, H. (2003). Identification of stimulatory and inhibitory inputs to the hypothalamicpituitary-adrenal axis during hypoglycaemia or transport in ewes. J. Neuroendocrinol. $15,572-585$.

Soengas, J. L. and Aldegunde, M. (2002). Energy metabolism of fish brain. Comp. Biochem. Physiol. 131B, 271-296.

Soengas, J. L., Sangiao-Alvarellos, S., Laiz-Carrión, R. and Mancera, J. M. (2007) Energy metabolism and osmotic acclimation in teleost fish. In Fish Osmoregulation (ed. B. Baldisserotto, J. M. Mancera Romero and B. G. Kapoor), pp. 277-307. Enfield, $\mathrm{NH}$ : Science Publisher.

van den Dungen, H. M., Buijs, R. M., Pool, C. W. and Terlou, M. (1982). The distribution of vasotocin and isotocin in the brain of the rainbow trout. J. Comp. Neurol. 212, 146-157.

Warne, J. M. (2001). Cloning and characterization of an arginine vasotocin receptor from the euryhaline flounder Platichthys flesus. Gen. Comp. Endocrinol. 122, 312319

Warne, J. M., Harding, K. E. and Balment, R. J. (2002). Neurohypophysial hormones and renal function in fish and mammals. Comp. Biochem. Physiol. 132B, 231-237.

Wendelaar Bonga, S. E. (1997). The stress response in fish. Physiol. Rev. 77, 591625 